\title{
СОЦИОЛОГИЧЕСКИЙ АНАЛИЗ МОНОГРАФИИ Ю. ГЕККЕРА «РУССКАЯ СОЦИОЛОГИЯ»
}

Первым на Западе, кто проявил серьезный интерес к российской социологии, был Юлиус Геккер ${ }^{1}$ В 1915 г. в Нью-Йорке он опубликовал книгу «Русская социология. Вклад в историю социологической мысли и теории» (Hecker 1915), поставив задачу дать по возможности полную картину развития социологии в России и показать ее самобытный характер. В своей книге он рассмотрел все ее направления и теоретические труды русских ученых - от П.Лаврова до социологов начала XX в.

В западной социологической литературе предпринимались и другие попытки анализа и оценки русской социологии, но все они были менее значительными, чем у Ю.Геккера. Автором одного из таких трудов был Казимир фон Келлес-Крауз, которому принадлежит обозрение основных идей русской социологии, включающее довольно ограниченный круг имен: П.Лилиенфельд, Л.Мечников, П.Лавров, Н.Михайловский, Н.Кареев, М.Ковалевский. Этот труд интересен тем, что в нем автор оценивает русских социологов с точки зрения вклада, внесенного каждым в мировую социологию, в развитие эволюционного подхода к социальным явлениям, в учение о солидарности, концепции прогресса, идей психологизма.

1 Юлиус Геккер (1881-1938), американский и российский исследователь русской социологии, малоизвестен даже в кругу отечественных специалистов. Во многом это объясняется языковым барьером, ведь оба издания его «Русской социологии», вышедшие еще в начале прошлого века, не переведены на русский язык. Личность Геккера весьма любопытна. Мы располагаем лишь скудной информацией о нем, но даже это дает понять, что он - человек с незаурядной биографией. Геккер был уроженцем Санкт-Петербурга, но как ученый сформировался в Америке.
Солидное исследование по русской социологии и общественной мысли в России до 1917 г. принадлежит А.Вукиничу (Vucinic 1976). Начало социологии в России датируется здесь 1861 г. и рассматривается в тесной связи с происходившими в России событиями: реформой 1861 г., общественными движениями, деятельностью крупных мыслителей и публицистов. Он видит проявление русской специфики в явлении нигилизма, характерном для поколения молодежи России 60-х годов (Кукушкина 2009: 482).

Особое внимание в связи с этой темой уделено произведению Тургенева «Отцы и дети». В главе, посвященной начальному этапу развития социологии в России, Вучинич обращается к наследию Герцена, Огарева, Чернышевского, Добролюбова, Писарева, Серно-Соловьевича, использует труды известных русских историков Карамзина, Соловьева и Ключевского.

Первые шаги русской социологии Вучинич связывает с именами Ножина и Щапова, Лаврова и Михайловского. Содержание отдельных глав книги составляет анализ нескольких особо заметных событий: становление научной социологии, субъективная социология, социальная теория анархизма, марксистская социология, философия истории в ее отношении к социологии. Предмет еще трех глав составляют персоналии, которые подобраны как выразители наиболее ярких тенденций, характерных для истории русской социологии: Б.Кистяковский с его социологическим синтезом, М.Ковалевский, соединивший в своих исследованиях исторический и социологический материал, и А.Богданов, который, как отмечает Вучинич, сочетал в 
своей социологической концепции элементы марксизма и неопозитивизма.

Несмотря на избирательное отношение автора к материалу русской социологии (в ней отсутствуют главы, посвященные натуралистическим течениям в позитивистской социологии России, нет целостного анализа неокантианской социологии) книга Вучинича является одной из наиболее серьезных работ, написанных о русской социологии за рубежом. Его труд отличается фундаментальностью, высокой степенью компетентности в вопросах, которыми он занимается, и стремлением к объективности оценок. В целом же работы западных авторов, посвященные истории русской социологии, немногочисленны. К тому же они, в лучшем случае, дают лишь краткие и не всегда самые важные сведения о ней в общих трудах по истории мировой социологии. Примером подобного рода изданий может служить опубликованная в Англии книга Х.Мауса «Краткая история социологии», в которой развитию социологии в России отведено всего несколько страниц (Maus H. 1962).

Русский материал в очень ограниченном объеме иногда включается в зарубежные справочные издания, энциклопедические словари. Приводимые в них данные слишком лаконичны и потому не могут дать представления о русской социологии как крупном явлении в мировой науке. В зарубежных изданиях можно встретить иногда работы, посвященные деятельности отдельных русских социологов. Но таких работ мало, они, как правило невелики по объему и в своей совокупности они не могут составить полной картины, хотя каждая из них сама по себе интересна и представляет научную ценность. Французский социолог Р. Вормс посвятил одну из своих статей своему русскому другу и коллеге М.Ковалевскому. Есть публикации других авторов, посвященные Е. де Роберти, Я.Новикову и другим русским социологам. Среди работ подобного рода выделяется исследование современного американского ученого, автора трудов по русской истории Дж.Биллингтона, посвященное творчеству Михайловского. «И, тем не менее, для историка социологии это всего лишь случайный набор фрагментов, а не систематический анализ особенностей развития и состояния русской социологии» (Кукушкина 2009: 481).

Некоторое оживление в изучение социологии России принесла новая волна эмиграции из России во второй половине XX в. Покинувший Советский Союз в 1974 г. В. Шляпентох начинает публиковать в США работы о политике и социологии в нашей стране. Основное внимание в них уделяется роли государственной политики и КГБ в развитии социологии, политической ориентации советских социологов, отношению политической элиты и партийного аппарата к социологии, отношениям между социологией и диссидентским движением, социологией и естественными науками (Кукушкина 2009). В Германии труды по истории русской социологии публикует Н.В.Новиков. Наряду с выходцами из СССР круг западных авторов, изучающих русскую социологию, постепенно расширяется. В 60-е гг. был подготовлен к печати сборник «Советская социология», в котором опубликованы статьи нескольких авторов из СССР (Осипова, Здравомыслова, Ядова и др.). Стали появляться различного рода обзоры, рецензии, библиографические издания, отражающие состояние социологии в нашей стране. Впервые в истории мировой социологии в международном энциклопедическом издании по военной социологии появилась статья по истории военной социологии в России, написанная современным русским социологом И.В.Образцовым. Но, тем не менее, признавая определенный сдвиг в области взаимоотношений русской и западной социологии, мы пока не можем говорить о масштабных переменах. А курс, взятый сегодня на подражание западным образцам во всех сферах жизни, в том числе в науке и культуре, вновь отодвигает отечественную социоло- 
гию на периферию. В среде социологов России все еще бытует мнение, что все достижения классического периода русской социологии это лишь факт истории науки и не более того. Однако, в своей монографии «Анализ личности в российской социологии: история и современность» мы призваны доказать обратное (Оганян 2015).

Интересом к социологии он обязан влиянию американского социолога Франклина Генри Гиддингса (Геккер является его учеником), представителя психологического направления в социологии. В Колумбийском университете Геккер получил ученую степень доктора философии за труд «Русская социология», который был впервые издан в Нью-Йорке и Лондоне в 1915 году. Рукописный вариант этого издания был отредактирован Гиддингсом. Следует отметить особый период жизни Геккера, который имел последствия для его мировоззренческих установок. Ученый в течение двенадцати лет жил и работал в Советском Союзе. Автор «Русской социологии» был очевидцем всех социальных преобразований, происходивших в это время в стране. Также Геккер активно работал в области образования. Результатом этих лет явилось второе издание «Русской социологии», вышедшее в Лондоне в 1934 г., более зрелый труд, включивший новые главы по русской и советской социологии и претерпевший эволюцию к марксизму. Третье издание книги вышло в свет в 1979 г. Ю.Геккер репрессирован и расстрелян в России в 1938 г. ${ }^{2}$

Наиболее ценным в книге Ю.Геккера является замечание о поверхностном знакомстве западных ученых с русской социологией и признание ее приоритетов в разработке ряда тем. Европейские и американские социо-

2 (См. биографию Ю. Геккера на болгарском сайте: URL: <http://virlib.eunnet.net/sofia/06-2003/text/ 0607.html>, дата обращения 05.01.2012; в российских энциклопедических изданиях сведения о Геккере отсутствуют). логи, отмечает он, пришли в свое время к этим ценным идеям «несколько более систематическим путем, нежели более ранние и никому неведомые русские» (Кукушкина 2009: 478). Имелась в виду, начатая русскими критика социалдарвинизма и органицизма. Кроме того, именно русские, подчеркивает Геккер, первыми заговорили о необходимости развивать психологические аспекты науки об обществе и человеке и основали традицию социологического психологизма.

Геккер дает в своей книге очерк предыстории научной социологии, обращаясь к ранним этапам развития общественной мысли в России и связывая свой анализ с политикой, с событиями государственной жизни.

Так, американский социолог считает, что социология в России была в зените во время великого реформаторского движения в 60-х и 70-х гг. и в меньшей степени в период промышленного развития в 90-е гг. и во время революции в конце русско-японской войны.

Рассматривая теории русских социологов, он особое внимание обращает на те их черты, в которых проявляется ее особая специфика. Так, в творчестве П.А.Кропоткина он выделяет то, что придает концепции этого социолога типично русские черты - идею взаимопомощи и при этом считает главный труд этого ученого «MutualAid» важнейшим чисто научным приобретением социологии.

Интересен тот факт, что Ю.Геккер рассматривает П.А.Кропоткина как представителя российского анархизма, которому были близки социологические теории субъективной социологии. Эта идейная близость, по мнению американского социолога проявляется в определенных взглядах:

- Согласно П.А.Кропоткину, все социальные объединения, животных или человека, держатся вместе благодаря чувству взаимного единства с каждым индивидуумом и со всем обществом в целом. Человек, взаимодейст- 
вуя с другими, руководствуется в своих действиях осознанием своего единства с каждым человеком.

- Основными факторами возникновения общества, согласно Кропоткину, являются: чувство единства или общности индивидуума со своим видом; групповое сотрудничество через взаимопомощь, а не борьба индивидов между собой.

- Свободная личностная инициатива и возможность каждого действовать; применение этой силы во время народных бунтов делает революцию непобедимой.

В социально-философском наследии В. Соловьева проблема взаимоотношений личности и общества была одной из главных. Согласно Соловьеву, человеческий индивид обладает потенциалом для реализации неограниченных возможностей. Он является уникальной формой бесконечного содержания. Возможности человека, отделяющие его от других животных, это три психологические характеристики: религиозность, чувство жалости и чувство стыда. Таковы основы, на которых строится вся система этики и социологии Соловьева.

Вкладом В.М.Коркунова, как представителя юридической школы, в социальные науки, по мнению Ю.Геккера, является то, что он преуспел в развитии системы права на основе социологических предпосылок. В социологическом творчестве В.М.Коркунова свое осмысление получает тема личности и общества.

Человек является не только подконтрольной частью своей социальной среды, но и динамической силой изменения и направления социальной жизни. Условия, способствующие развитию психической жизни человека, также благоприятны для жизни сообщества. В обществах, где развитие индивидуальной мысли подавляется, рост социального идеала становится невозможным.

Н.М.Коркунова некоторые исследователи считали представителем юридической школы в истории российской социологии (Волков, Добреньков и др. 2003), а другие - к психологической (Новикова: 1996). Первые исходили из того, что одной из главных задач своего творчества Н.М.Коркунов считал применение обобщенного западноевропейского опыта к российской действительности. Это выражалось в основных проблемах, рассматриваемых им: специфика понятия «правовое государство»; главные гарантии правового государства; принципиальное различие понятий «закон» и «указ»; власть как система субъектно-объектных отношений господства; специфика государственной власти; структура публичной власти и государства; государство как комплексная система связей между индивидами и должностными лицами и др.

Вторые подчеркивали психологическую основу его социально-правовой теории: анализ общества как результата психического единения людей; психологическая преемственность поколений как залог эффективности развития общества; проблему соотношения общества и личности в контексте выяснения степени свободы личности.

Мы придерживаемся точки зрения второй группы исследователей и рассматриваем проблему общества и личности в творчестве Н.М.Коркунова как представителя психологической школы российской социологии (Оганян 2013: №6 (13)).

Особенно высоко оценивает Геккер историко-сравнительное направление социологии Ковалевского, социолога, который, в отличие от других русских ученых, занимался своими исследованиями вне какого бы то ни было партийного движения.

Кроме того, американский исследователь отмечает ценность иллюстративных этнографических материалов, использованных М.М. Ковалевским при рассмотрении проблемы происхождения религии, которые позднее были заимствованы и по-новому истолкованы Дж.Гар- 
рисоном в «Темис» и Э.Дюргеймом в «Элементарных формах религиозной жизни».

Среди всех российских социологов, Ю.Геккер отдельно выделяет Е.В. де Роберти и Я.А. Новикова, как более или менее оторванных от социально- политических проблем своей родины, и внесших значительный вклад в развитие мировой социологии, распространение отечественной социологии в среде западных ученых.

Оба они, эмигрировав во Францию, писали свои работы на французском языке под влиянием французской мысли и жизни. Е. де Роберти издал свою первую работу по социологии (1881) одновременно на русском языке и на французском языке. Книга была намного более благоприятно встречена на берегу Сены, чем Невы.

С нашей точки зрения, Ю.Геккер подробно не анализирует методологическую проблему взаимоотношений социологии и психологии в творчестве Е.В.Де Роберти. Она представлена посредством анализа следующих аспектов (Оганян 2013: 156-164): задачи и цели социолога как исследователя; специфика изучения надорганических явлений психологом; роль социологии в развитии психологических исследований; методологические основы психологии, предметное поле изучения действительности психологом и социологом.

Идеи Е.В.Де Роберти о психическом развитии человека в группе, коллективном психологизме, солидарности, повлияли на формирование и развитие школы «человеческих отношений» Э.Мэйо в управленческой мысли. Также как Де-Роберти противопоставлял биологическому редукционизму Г.Спенсера свой социальный психизм, представители школы человеческих отношений выступали против авторитарных методов управления, единоначалия, преобладания формальной структуры управления над неформальной, которой придержи- вались сторонники классической школы управления (Оганян 2013).

Основы социально-психологического подхода в управлении были сформулированы Е. Де Роберти, так как в изучении неформальной структуры организации такие понятия как психологическое взаимодействие, коллективная психика являются ключевыми.

В социологической концепции Е. де Роберти много внимания было уделено проблеме социально-психологического общения и нормативно-этическим аспектам межличностного взаимодействия. Личность провозглашалась единственной целью прогресса и главным критерием общественного развития.

Психологическая школа Е. де Роберти способствовала появлению новых перспективных проблем в социологии и психологии управления и социальной психологии, в частности теории малых групп, способствовало разработке теории личности, заложило фундамент для развития школы человеческих отношений Э.Мэйо, дало импульс для появления различных концепций стилей управления.

Новиков как бескомпромиссный враг всех форм деспотизма часто, в своем научном творчестве, нападал на политические учреждения России, и это может быть основной причиной запрета на распространение его книг в родной стране. Тем не менее, Ю.Геккер считает, что как только свобода печати увеличится в России, его французские работы будут переведены на русский язык и повлияют на российскую социологическую мысль.

Ю.Геккер критикует Я.Новикова за то, что он использовал негарантированную биологическую аналогию, грубо относился к обществу.

Отдельное место в монографии Ю.Геккера занимает анализ направлений славянофильства и западничества. Ведущие направления западничества он классифицирует следующим образом: 1. Теократическая тенденция 30-х гг. с Чаадаевым в качестве своего главного предста- 
вителя и теоретика; 2. Гуманитарная тенденция 40-х гг. с Белинским, как ведущим представителем; 3. Популистская философия 60-х, для которых Герцен и другие проложили путь в предыдущее десятилетие, но которое наиболее тесно связано с именем Чернышевского.

Важно отметить, что В.Белинского, Н.Чернышевского и А.Герцена американский социолог рассматривает как предшественников русской субъективной школы, анализ которой будет представлен позже. Так, В.Белинский пытался найти решение проблемы истинных отношений между обществом и личностью, являющейся главной для субъективистов.

\section{Анализ субъективной школы в монографии Ю.Геккера}

В своем труде Геккер анализирует основные школы и направления русской социологии. Из всего содержания книги Ю.Геккера Н.И.Кареев выделил какнаиболее удавшуюся автору часть текст, посвященный анализу субъективной социологии. Ю.Геккер охарактеризовал это направлениекак истинно русское и наиболее значительное по сравнению с другими направлениями. Проделанный им тщательный анализ (84 страницы текста монографии) касается главным образом философских и методологических предпосылок субъективной социологии, роли понятия солидарности в теории социального прогресса, развиваемой П.Лавровым, Н.Михайловским и С.Южаковым, их вклада вразработку теории личности и учения об индивидуальности (Оганян 2013). Кареев отмечает, что идеи субъективной школы, по мнению Геккера, неустарели ко времени написания его книги, а субъективный метод вскоре получил новую разработку в виде антропотелеологического методав исследованиях американского социолога Лестера Уорда (Кареев 1916: №4. 300).

Рассмотрим анализ субъективной школы в монографии Ю.Геккера более подробно. В первой главе по субъективной школе Ю.Геккер подробно рассматривает вклад П.Лаврова в социологию. Американский социолог выделяет три главных теории в творчестве российского социолога: социальной солидарности или социального контроля; индивидуальности или личности; социального прогресса.

В анализе теории личности П.Лаврова Геккер уделяет особое внимание рассмотрению биологического аспекта происхождения индивидуальности, ее историческим формам и процессу эволюции. П.Лавров подробно исследует животный мир, просматривая эволюцию человека начиная с низших форм его существования. Тем не менее, российский социолог не останавливается на этом, и продолжает рассматривать индивида уже как продукт группы, позволяющий прийти к анализу проблемы личности и социальных форм.

В своем анализе особенностей теории личности П.Лаврова, с нашей точки зрения, Ю.Геккер не уделяет должного внимания рассмотрению: специфики «критически мыслящей» личности, ее характеристикам, качествам, в совокупности способствующим достижению в обществе социального прогресса; классификации типов личности (Оганян 2012: 16-26).

Ю.Геккер раскрывает формулу прогресса по П.Лаврову, при этом не рассматривая проблему взаимоотношений личности и общества, роль нравственного идеала в развитии общества, личность как производную культуры своего времени.

Общество для Лаврова - это совокупность социальных (культурных) форм, которые являются продуктом творчества личностей и реально существуют лишь в личностях, а потому последние всегда имеют право и обязанность стремиться в соответствии со своими потребностями к их изменению, замене патологических форм здоровыми. Любой вопрос науки об обществе, это вопрос об удобстве данных форм для данных людей. 
Несмотря на то, что личность и общество друг без друга немыслимы, но в целях теоретического понимания человеческой деятельности следует различать двоякого рода явления - индивидуальные и социальные. Это различение оправдывается тем, что в самой личности, независимо от окружающей среды находятся различные самостоятельные начала. Исследование этих начал и должно быть предметом теории личности (Кареев 1901: 51).

Прежде чем им была поставлена проблема общества, он уже разработал основные положения своей теории личности, и, изучая потом общество, он только в личности видел реальность, в обществе своего рода фикцию - мысль, далекую от исходного пункта самого построения социологии. Теория личности впоследствии доминировала в социологическом мышлении Лаврова.

И личность, и общество он брал вначале не такими, какие они есть, а каким они должны быть, интересуясь социологической и психическою действительностью, главным образом, со стороны представляемых ею условий для возможного осуществления идеала совершенной личности и совершенного общества (Кареев 1922: 243).

Лавров включал в область ведения социологии и нравственный принцип о справедливом общежитии, вследствие чего сводил в научном построении отвлеченную социологию на теорию справедливого общежития, которая для него опиралась в значительной мере на субъективные категории этики. Другими словами, в социологии Лаврова общество было не только научным понятием, но и этической проблемой. В само понятие общества он вносил телеологический момент, поскольку в обществе видел совокупность форм взаимодействия, инстинктивно или сознательно соединенных реальными единицами для удовлетворения своих потребностей.
Таким образом, вся социология Лаврова выступает как целостная система, где одна проблема служит продолжением другой. Отсюда становится понятным положение, что, несмотря на пестроту и кажущуюся разнородность многочисленных работ Лаврова, все они, представляют труды, разрабатывающие отдельные главы социологии - науки о солидарности (Оганян 2012).

Интересно, что Ю.Геккер в главе 3 показывает близость идей В.Чернова с П.Лавровым, рассматривая его как последователя субъективиста. Эта выражается в следующем:

1. В.Чернов анализирует человека как основную движущую силу истории. Взаимодействуя с окружающей средой, он создаёт так называемую искусственную среду или культуру.

2. Как и другие российские субъективисты, В.Чернов стремился поддержать концепцию сильного индивидуализма, и в то же время, сохранить принципы социальной ответственности. Как и Лавров, он пытался выявить социальные и реалистические требования долга, которыми бы люди руководствовались в отношениях с обществом.

3. Задачей социологии является определить идеал. Идеал должен удовлетворять всем естественным инстинктам и интересам человека.

Оценивая социологическое творчество П.Л.Лаврова Ю.Геккер утверждает, что он был одним из первых, показавших ошибочность и недостатки биологической аналогии в социологии, и стремившихся основать социологию на психологии и этике.

Американский автор подчеркивает, что критически мыслящие индивиды как агенты социального прогресса, по П.Л.Лаврову, являются теми молодыми русскими революционерами, ставшими его последователями.

В заключении Ю.Геккер приходит к выводу, что социология П.Л.Лаврова действительно 
русская, поскольку она была стимулирована и обусловлена общественно-политическими движениями в России того времени. Ее целью было оправдание прогрессивных элементов России в их борьбе против самодержавия, а также поддержка его последователей с научно обоснованной программой. Помимо тенденций, существует множество актуальных ценностей в работах П.Лаврова, которые должны найти свое заслуженное признание.

Вторая глава раздела о субъективной школе посвящена социологической системе Николая Константиновича Михайловского. Американский социолог дает достаточно обширный анализ основных положений социологии Н.Михайловского, структурируя свои взгляды следующим образом: с начала он рассматривает философские и методологические основы его социологии - методы, взаимоотношение социологии с другими науками, а затем подробно анализирует его теории: борьбы за индивидуальность; индивидуализации и разделения труда и некоторые аспекты теории героев и толпы.

Теория борьбы за индивидуальность Н.К.Михайловского представлена посредством анализа таких аспектов как: биологический, психологический, экономический, исторический.

Ю.Геккер подчеркивает, что Н.К.Михайловский - один из немногих русских социологов, который имеет развитую собственную социологическую систему, несмотря на то, что она не совсем развита, не собрана в одной конкретной социологической работе.

По мнению Ю.Геккера теория Н.К.Михайловского не сильно отличается от органической школы в социологии, которую он критикует. Он только рассматривает понятие индивидуальности для организма. Человечество упорно стремиться к социальной солидарности и индивидуализации, поэтому жесткий индивидуализм Н.К.Михайловского является скорее идеалом, чем исторической и научной необходимостью. Однако, несмотря на это, американский исследователь отмечает, что Н.К.Михайловский внес ценный вклад в качестве одного из первых авторов, предложивших психологический анализ социальных явлений.

Н.Михайловский кажется Ю.Геккеру несправедливым в своем отношении к обществу, поскольку он не учитывает то огромное влияние, которое оно оказало на личность. Но это можно простить ему, считает Ю.Геккер, если мы вспомним, что Н.Михайловский занимался социологией не как профессор, который имеет только научные интересы, но и как лидер движения, борющегося против самодержавия. Как и теория П.Лаврова, социологическая система Н.Михайловского была главным научным обоснованием для общественно-политических движений. Цель этой системы - защитить человека от слишком жесткого деспотичного контроля, и он пытался примирить общество и личность, рассматривая «правду-истину» и «правду-справедливость». Его сердце билось тепло для своего народа, интеллектуальным вождем и руководителем которого он был для целого поколения. Таким образом, отмечает Ю.Геккер, Н.К.Михайловский является значимой фигурой для своего народа и поколения, он внес вклад в социологию в целом, хотя его с опозданием признали в научном мире.

Одним из недостатков Ю.Геккера в анализе социологической системы Н.Михайловского мы считаем то, что он не уделил должного внимания рассмотрению личности как отдельной единице социологического анализа; различным проблемам социальной психологии - психологии толпы; более подробному и углубленному анализу теории героев и толпы как проявлению психологической ориентации социологии Н.К.Михайловского.

Н.Михайловский в своей социологии рассматривал многосторонне развитую личность. Это «профан», идеальный тип, широко разви- 
тый, интересующийся многими областями жизни, науки, искусства (Оганян 2012).

Личность как предмет социологического анализа, по Н.Михайловскому, - это сознательно-целесообразное существо, которое оценивает действительность, ставит цель и стремится ее реализовать (Оганян 2012). Целеполагание - это качественное отличие человеческого общества. Из этого Н.Михайловского приходит к выводу о том, что цель требует субъективной оценки, поэтому целепогалание можно познать только при помощи субъективного метода.

С конца 70-х годов в социологии Н.Михайловского ведущее положение заняла проблема социальной психологии - психологии толпы. Российский социолог преследовал две цели: 1. Рассмотрение психологических особенностей поведения личностей в группе и массе людей с целью выяснения психического механизма воздействия индивида на массу; 2. Исследование роли социальной среды в формировании психологии индивида и массы (Оганян 2013).

Центральной темой Н.К.Михайловского в его теории героя и толпы является проблема общения как между героем и толпой, так и межличностного общения в толпе. Механизмами общения он считал внушение, подражание, заражение, противопоставление. Из них главные - подражание толпы герою и взаимоподражание людей в толпе.

Н.Михайловский широко пользовался понятиями «психическая зараза» и «социальный гипнотизм» как выражениями внушения или подражания, с помощью которых он пытается объяснить движения масс. Кроме того, подражанием, присущим как «толпе», так и отдельному лицу, он стремился объяснить единство индивидуальной и социальной психологии.

К психологическим факторам развития общества Н.Михайловский относил подражание, общественное настроение и социальное поведение. Н.Кареев, высоко оценивая социологические труды Михайловского, видел в них по- пытку построить общественно-психологическую теорию.

Михайловский был первым, кто разработал в социологии проблему подражания, изложив свою теорию в статье «Герои и толпа», то есть за восемь лет до появления книги Тарда «Законы подражания» (1890) и за два года до первых заметок Тарда в «Revuephilosophique» (1884) 3 .

В заключении охарактеризуем основные положения социально-психологической концепции личности Н.Михайловского (Оганян 2012): он считал, что личность и развитие общества необходимо изучать на трех различных уровнях - социальном, с точки зрения экономического разделения труда, создавая наилучшую организацию, которая должна вести к сотрудничеству и солидарности; биологическом, в плане «борьбы за индивидуальность» как извечного биологического закона, и психологическом, анализируя психологическое взаимодействие личности и масс; - он предложил оригинальное понимание формулы прогресса общества и личности. Если для развития индивида верна формула: от однородного к разнородному, то для общества эта форма должна быть обратной: от разнородного к однородному. Последнее означает единство свободы, равенства и солидарности для всех в обществе; - в связи с изучением проблемы подавления индивидуальности Н.Михайловский основал и разработал новое направление в науке - массовую психологию, область, в которой стало возможным открыть различные патологические явления личности и заданный внешними условиями

3. Кареев Н. (Памяти Михайловского как социолога), Колосов Е. (Очерки мировоззрения Михайловского Н.) и в наши дни А.Казаков (Теория прогресса в русской социологии конца XIX века) высказывали справедливую мысль, что Михайловский выдвигал и решал социологические проблемы, которые в западной социологии ставились значительно позднее, например, роль разделения труда в социологии Дюркгейма, теория подражания Тарда и целый ряд других проблем. 
психический и социальный автоматизм личности (Оганян 2013: №2-3 (10)).

Третья глава раздела о субъективной школе посвящена социологии Сергея Николаевича Южакова. Рассматривая социологическое творчество российского социолога, Ю.Геккер анализирует его двухтомную работу «Социологические этюды» (1896), в которой наиболее полно отражены социологические воззрения автора. «Социологические этюды» - это главная теоретико-социологическая работа С.Южакова, на создание текстов, вошедших впоследствии в двухтомник, он потратил более 20 лет своей жизни. В этой работе изложены взгляды русского социолога на предмет и задачи социологии, природу социального и биологического, на происхождение нравственности и ее месте в общественной жизни, на движущие силы социального прогресса и др.

Американский социолог дает достаточно многоплановый анализ основных положений социологии С.Южакова, структурируя свои взгляды следующим образом: сначала представляет социологическую позицию российского социолога, теоретико-методологическую основу его социологии, а затем подробно рассматривает его теорию общества. Теория общества С.Южакова представлена посредством анализа таких аспектов, как: причины и специфика процесса социализации; влияние законов органической жизни и среды на социальные процессы; этический аспект взаимоотношений личности и группы; экономическая активность как фактор развития культурной и социальной деятельности. Ю.Геккер подчеркивает, что исследовать проблемы социологии С.Южакова побуждали реальные политические силы, идеи которых он не разделял; Геккер также считает, что Южаков был одним из лидеров народников, которые стремились изменить общество и разделяли идею прогресса. Таким образом, С.Южаков не только внес огромный вклад в развитие субъективной школы в социологии, он
- сотоварищ П.Лаврова и Н.Михайловского в деле осуществления социальных реформ в народническом духе. Ю.Геккер не считает, что С.Южакову удалось создать синтетическую систему социологии, к чему тот стремился. Американский социолог подчеркивает, что С.Южаков привнес в социологию и подчеркнул несколько важных истин, которые являются общепринятыми на сегодняшний день. В частности, он четко показал, что процесс социализации - это результат равновесия между внутренними и внешними взаимоотношениями жизни и окружающей среды, когда жизнь приспосабливается к среде и одновременно приспосабливает среду к своим потребностям, в результате чего создается «социальная культура». Американский социолог отмечает, что С.Южаков, как и П.Лавров, пытается синтезировать основы социологических теорий, собирая их вокруг понятия личности. С.Южаков считает, что личность может с помощью своих социальных и экономических излишков адаптировать среду под себя и направить ее к цели. По его мнению, личность - единственный активный элемент общества, который создает социальные условия и одновременно является их продуктом 2. Одним из недостатков анализа социологической теории С.Южакова, который провел Ю.Геккер, мы считаем то, что он не уделил должного внимания рассмотрению таких понятий, как личность, активность, культура при изучении различных социальных проблем (Оганян 2012).

В четвертой главе раздела о субъективной школе Ю.Геккер рассматривает вклад Н.Кареева в социологию. Американский социолог структурирует свой анализ следующим образом:

- Философские и методологические предположения Н.Кареева;

- Что такое общество в его различных аспектах?

- Сущность исторического процесса и роль личности в истории;

- Социологическая проблема прогресса 
Н.Кареев, отмечает Ю.Геккер, не защищает субъективный метод, но подчеркивает субъективный фактор, который играет важную роль в жизни общества и не может быть игнорирован общественной наукой.

Следовательно, согласно Н.Карееву, общественная жизнь и вся история - один и тот же продукт взаимодействия сознательной и бессознательной деятельности людей с природой и друг с другом, поэтому деятельность личности является социальным фактором. Таким образом, для социологии основным объектом исследования является индивид в своей общественной деятельности.

Здесь мы полностью согласны с мнением Ю.Геккера, поскольку личность для Н.Кареева исходный и ключевой субъект социальной жизни, стремящийся переработать своей мыслью и деятельностью целое в соответствии со своими потребностями. Очевидна близость Н.Кареева к взглядам П.Лаврова, тем не менее, нужно видеть и их существенное отличие. У П.Лаврова (в «Исторических письмах»), подчеркивал Н.Кареев, на первом плане «...вопрос о том, как должна идти история, как должны вести себя отдельные личности, тогда как для нас особую цену имело бы исследование того, как совершается история и какую в ней роль играют эти личности» (Кареев 1914: 71).

Исходя из такого понимания личности, общество для Н.Кареева - это комплексный продукт биологических, психологических факторов и условий среды, но психологический фактор играет доминирующую, организующую роль, которая выражается посредством объединения индивидов в общество.

Продолжая раскрывать сущность общества в социологии Н.Кареева, Ю.Геккер рассматривает проблему взаимоотношения личности и общества.

С нашей точки зрения эта проблема представлена в концепции Н.Кареева посредством анализа понятий надорганической среды, куль- туры, социальной организации, личностной инициативы и других (Оганян 2013: № 07). Это показывает, что личность является для российского социолога системообразующей составляющей в структуре и развитии общества. Общество должно создать соответствующие условия для развития и самореализации личности.

В этом отношении Н.Кареев является идейным продолжателем П.Лаврова и Н.Михайловского, отстаивавших в своих концепциях принцип личности.

Анализируя тему личности в социологии Н.Кареева, Ю.Геккер не раскрывает сущность понятия нравственной личности, а эта составляющая имеет одной из важных значений для понимания специфики подхода российского социолога.

Это понятие раскрывается Кареевым $\mathrm{H}$. посредством анализа взаимоотношений понятий личности и индивидуальности, а также сущности общественной деятельности (Оганян 2013: № 8 (часть 5)).

В обеих своих работах: «Мысли об основах нравственности» и «Мысли о сущности общественной деятельности» Кареев Н. рассматривает индивидуального человека, и все различие заключается в том, что в одном случае идет речь об индивидууме, как о нравственной личности, в другом - как об общественном деятеле; в первом случае нравственная личность рассматривается в своих отношениях к самой себе и в частных отношениях к другим людям, во втором имеется в виду именно только общественная деятельность индивидуума, его публичная, а не частная жизнь (Кареев 1901; Кареев 1895).

Ю.Геккер подчеркивает психологический аспект в понимании прогресса Н.Кареевым и дает такое определение прогресса - это любые средства, способствующие совершенствованию индивида в его психических отношениях или совершенствующие материальные отношения 
членов общества или же постепенный рост общественных сил, что благоприятствует развитию личности и контролю над природой я использованию природы. Если исходить из этого понятия прогресса, утверждает Н.Кареев то прогресс имеет интеллектуальные, моральные, социальные и экономические фазы.

Развивая и дополняя мысли Ю.Геккера об идеях Н.И.Кареева, прогресс как общее понятие включает в себя, по Н.Карееву, пять более частных: прогресс умственный - воспитание способностей к духовным интересам; прогресс нравственный - воспитание способности действовать по убеждению и улучшение принципов этики; прогресс политический - развитие свободы; прогресс юридический - развитие равенства; прогресс экономический - развитие солидарности и кооперации. Российский социолог стремился охватить понятием прогресса все стороны жизни общества, и в этом его сходство с Е. де Роберти (Оганян 2013).

По сравнению с народнической социологией Н.Кареев сделал шаг вперед в своей попытке избежать узкого понимания социального прогресса, включив в его содержание важнейшие области человеческой деятельности. Интересно, что предлагаемая Н.Кареевым формула прогресса заключала в себе три элемента, которые он подчинял главной цели прогресса - развитой и развивающейся личности.

Первый элемент - идеал. Им является развитая личность при наличии индивидуальной свободы и общественной солидарности. Второй элемент состоит в определении путей достижения идеала. Его осуществление заключается в переделке посредником критической мысли культуры, быта и социальной организации. Третий элемент - выражение закона самого прогресса. Состоит он в самоосвобождении личности, в том, что личность подчиняет себе надорганическую среду.
В главе, посвященной социологии Н.Кареева, Ю.Геккер неправомерно упускает из виду и не анализирует личностные качества, характеристики, сущность индивидуальности, способствующие достижению прогресса в обществе (Оганян 2013: № 2 (октябрь)).

Для воззрений Н.Кареева характерен аспект понимания общественных отношений, особенно присущий социологической традиции народничества, когда определяющим или феноменом общественных отношений признавалась активность субъекта, его социально-психологические особенности. Анализируя эту сторону понимания социального, Н.Кареев решающее значение придавал так называемой инновации - личной инициативе, изобретательству, творчеству. Содержание этих инновационных способностей личности, как психосоциолог, Н.Кареев выводит из биопсихологических особенностей самих индивидов.

Основные качества, составляющие внутреннюю сущность человека по Н.Карееву личная оригинальность и индивидуальная инициатива, которые способствуют развитию творческих способностей личности. Эти качества обусловлены преимущественно прирожденными способностями человека и основываются на его самосознании.

Рассуждения Н.И.Кареева об индивидуальности, подтверждают значимость главного, отличительного признака личности, на который указывал еще П.Л.Лавров. Оба мыслителя придают важное значение критике, самосознанию и творчеству в процессе формирования личности как общественного существа. Эти качества являются основой совершенствования как отдельного человека, так и общества в целом.

Н.И.Кареев в своей концепции личности рассматривает не совокупные отношения людей, которые складываются в обществе, а отношения человека к человеку как психических индивидуумов. Придавая большое значение 
силе общественного мнения, с действием которого должен считаться любой политический деятель, Н.Кареев полагал, что общественное суждение создается и распространяется лишь теми людьми, которые способны создавать новые идеи, обладают инициативой, способные к творчеству и инновациям. Только люди, обладающие подобными свойствами могут заниматься вопросами регуляции общественных отношений.

Н.Кареев подчеркивал, что только детальная разработка вопроса о том, как зарождается и распространяется инновация в разных сферах культуры (в языке, в религии, в искусстве, в праве и т.д.) может дать в результате полное представление об этом предмете.

Для более полного понимания специфика концепции Н.Кареева выявим факторы и условия, способствующие формированию его взглядов.

1. Преувеличение роли психологического фактора в общественной жизни в концепции Н.И.Кареева может быть обусловлено: борьбой, которую он вел против недооценки и даже игнорирования роли психологического фактора; - это вытекает из обоснования им значимости субъективного элемента в философском осмыслении истории и необходимости принимать во внимание результатогы деятельности людей при научном обосновании проблем общественного развития.

2. Формирование мировоззрения Н.Кареева происходило в сложных и противоречивых условиях пореформенной России под сильным воздействием идей революционной демократии, народничества (влияние идей П.Лаврова), а также доктрин европейского либерализма. В этом контексте Н.Кареев первую очередь воспринял идею свободы и независимости личности.

3. Большой практический опыт способствовал разработке проблем общего образования и самообразования молодежи, которым Н.Кареев также придавал большое значение. Преподавание он считал главным делом жизни.

Социологией Н.Кареева, Ю.Геккер завершает свой анализ субъективной школы. Американский социолог выделяет некоторые общие черты, объединяющие субъективистов - все они: - придерживаются принципов позитивистской и эмпирической философии; - приспосабливают научную классификацию Конта; - смотрят на психологию и этику как на переходные и относительные, независимые науки, которые находятся между биологией и социологией; отвергли в принципе дедукцию биологическоорганической школы социологии и безличностный, механический взгляд школы экономических детерминистов; - согласны, что динамика общественного прогресса - это комплекс физических, биологических, психических и экономических сил; - подчеркивают, однако, психо-социальную деятельность и работу критически мыслящих личностей как определяющий фактор прогресса внутри организованного общества.

Давая оценку деятельности субъективистов Ю.Геккер отмечает, что они сделали хороший задел по разработке комплексного органического синтеза социологических теорий, продолженный многими социологами как в Европе, так и в Америке. Особенно он выделяет Н.Михайловского, признавая его наиболее оригинальным среди русских социологов.

С нашей точки зрения субъективная школа обладала рядом преимуществ, и ее представители предложили ряд новых идей, во многом опередивших развитие отечественной и мировой социологии:

1. Специфичность и неординарность теорий субъективной школы проявились и в выдвижении ряда положений и подходов, которые предвосхитили важные открытия в науке более позднего времени. Мысль о необхо- 
димости различать науки по характеру объектам много времени спустя получила развитие в новом направлении в философии и социологии - неокантианстве . Одним из основных требований методологии неокантианства было разделение наук на науки и природе и науки о культуре и разработка соответствующей такому разделению методологии.

2. Этико-психологическая (субъективная) социология во многом предваряла идеи М.Вебера, Г.Зиммеля, будущего символического интеракционизма, полагая, что «выражением социальности является индивидуальность, что у общества нет какого-либо самостоятельного существования как особого состояния, внешнего индивиду; оно состоит из событий, то есть оказывается процессом постоянного созидания» (Оганян 2012: 117). Задача социолога - понять и интерпретировать мотивы социальных действий.

Американский социолог особо выделяет первенство российских социологов (имеются в виду Михайловский, Лавров, Кареев) во многих вопросах, утверждая, что у них были хорошие идеи, оставшиеся неизвестными западноевропейским и американским социологам, которые пришли к тому же самому независимо, несколько более систематическим путем, нежели более ранние и никому неизвестные русские. Именно они попытались обосновать тезис о необходимости изучения психики отдельной личности, как основе социальной психологии и возводимой на ней социологии. В основу познания общества, согласно Н.Карееву, должно быть положено изучение природы человека, главным образом - духовной стороны человеческой личности, т.е. индивидуальной психологии.

Ю.Геккер, подчеркивая влияние социально-политического фактора в развитии субъективистского направления, подчеркивает, что эта первая и передовая школа русской социологии была разумным усилием дать интеллектуальное направление социально-политическому движению людей, стремящихся к основанию демократии. Этот факт наложил определенный отпечаток на нее и превратил данную школу в особую, и прежде всего в чисто русскую социологию «романтического» периода русского революционного движения. Марксистская критика этой субъективной школы была дана Плехановым, и в настоящее время, с точки зрения Ю.Геккера, эти идеи полностью отвергнуты в связи с победой исторического материализма в России.

В этом отношении с Ю.Геккером можно поспорить, поскольку ситуация изменилась, и современная социология доказывает обратное. Так, идеи субъективистов были актуализированы нами посредством: формирования образа современного руководителя на основе критически мыслящей личности в концепции П.Лаврова; реализации идей концепции личности Михайловского Н. в условиях кризиса современного общества; социально-психологического анализа управления организацией в концепции личности С.Южакова (Оганян К. 2012: 110-115).

\section{Анализ марксистской социологии в монографии Ю. Геккера}

Второе место по объему страниц, В монографии американского исследователя, по сравнению с субъективной школой (64) занимает марксистская социология в России (28), которой посвящена первая и вторая глава третьей части «Разносторонние школы и течения русской социологии».

Среди представителей легального марксизма Ю.Геккер анализирует социологические идеи Г.Плеханова, от нелегального направления - П.Струве и М.Туган-Барановского. Рассмотрим некоторые особенности их социологических подходов.

Ю.Геккер структурирует анализ научного творчества Г.Плеханова следующим образом: 
- Критика Г.Плехановым немарксистских субъективных социологов и русских народников;

- Философские и методологические предпосылки позиции Плеханова;

- Краткий анализ его теории социальной эволюции

Критикуя субъективных социологов, Г.Плеханов, главным образом, выступает против исключительной роли личности в истории как фактора прогресса. Он рассматривает эту позицию как устаревшее утопическое учение, которое не может успешно противостоять критике диалектического материализма.

В сущности, утверждает марксист, субъективисты никогда не умели не только решить, но даже и правильно поставить вопрос о роли личности В истории. Они противополагали деятельность «критически мыслящих личностей» влиянию законов общественно-исторического движения и таким образом создавали как бы новую разновидность теории факторов: критически мыслящие личности являлись одним из факторов названного движения, а други фактором служили его же собственные законы.

В этом отношении, мы не поддерживаем точку зрения Г.Плеханова, поскольку субъективисты имели четко выстроенную концепцию личности, в которой не допускалось ее полное поглощение обществом. Личность и общество не были так жестко противопоставлены друг другу. В частности, П.Лавров подчеркивал, что между ними происходит постоянное взаимодействие и предъявлял обществу такое требование: «здоровое общежитие и безопасное общежитие невозможны вне рационального экономического общежития (под которым у него подразумевался социализм)» (Оганян 2012: 20). Идеалом для П.Лаврова было сочетание личного развития и общественной солидарности. Движение общества в сторону такого сочетания он называл прогрессом.
Анализируя природу и сущность великого человека, по Г.Плеханову, Ю.Геккер ограничивается этим, хотя тема личности у российского марксиста раскрыта более многогранно.

Личность в творчестве Г.Плеханова представлена посредством анализа таких аспектов как: проблема роли личности в истории; факторы, определяющие появление героя, его личностные особенности и влияние на общество; роль народных масс в истории (Оганян 2014: Т. 14, № 6).

В заключении, выражая свою оценку научного творчества Г.Плеханова, американский социолог отмечает критичность его мышления, поскольку он игнорирует почти всю, проделанную социологами работу со времен Конта, и ограничивает свою критику в социологическом подходе, которому предшествовал рост позитивистской социологии. Поэтому Г.Плеханов больше подчеркивает диалектику за счет многочисленных достижений науки в области биологии и психологии.

Рассматривая социологическое творчество П.Струве, американский социолог делит его на три периода: ортодоксального марксизма, перехода от марксизма к ревизионизму, отрицания диалектического материализма Маркса и обращение к идеализму и социальному субъективизму. Это свидетельствует о глубоком знании Ю.Геккером специфики социологии российского социолога.

Обратимся к последнему этапу творчества П.Струве, на котором более поздние сочинения показывают его как идеалиста. Ю.Геккер даже утверждает, что в этом отношении российский социолог принадлежит к субъективистской социологической школе. Это выражается в том, что П.Струве подчеркивает важность личности в социальной эволюции, и считает, что политическое совершенствование общества зависит от образования личности. Тем не менее, Ю.Геккер не рассматривает личность как отдельный самостоятельный объект в творчестве П.Струве. 
Личность представлена через рассмотрение таких аспектов как: проблема взаимодействия личности и общества; роль культуры в развитии личности и их взаимозависимость; идея «личной годности»; правовая автономность личности (Оганян 2014: Т. 14, № 6).

Особый интерес вызывает идея «личной годности», предложенная П.Струве. «Личная годность» - это совокупность некоторых духовных свойств личности: выдержки, самообладания, добросовестности, расчётливости, на основе которых создается и развивается более производительная общественно-экономическая система. Эта идея является неотъемлемой чертой либерализма, каким его хотел видеть П.Струве: «Если в идее свободы был заключён вечный идеалистический момент либерализма, то в идее личной годности перед нами вечный реалистический момент либерального миросозерцания» (Струве 1999: 81). Позже, П.Струве писал, что личная годность - "определяющее всё моё мироощущение и центральное для моего нравственного, социального, и политического мировоззрения словосочетание» (Струве 1926: № 352).

В результате проблема личной годности это альтернатива эгалитаризму и иерархизму, это своеобразный мост между экономикой, моралью и религией, без которой невозможно экономическое выздоровление России. Идея «личной годности» П.Струве - как религиознонравственно-экономическое обоснование идеала правовой личности - дополняла спектр «типов» личности, предложенных в истории русской социологии: «критически мыслящая личность» П.Лаврова (Оганян 2012: №4 (55)); модель «идеального» типа личности Н.Михайловского (Оганян 2012: № 146); «нравственная личность» В.Хвостова (Оганян 2013); «идеал нравственной личности» как цель прогресса у П.Новгородцева; личность как «интегральная» система у П.Сорокина; личность как «интеграль- ное» понятие у А.Стронина (Стронин 2013: 132177; Оганян 2011: № 50) и др.

Одной из ключевых проблем своего социально-философского творчества П.Струве определял как роль культуры в развитии личности и их взаимозависимость.

Культура и личность, по П.Струве, находятся в тесной внутренней связи между собой. Личность творит культуру, а задача культуры утверждение свободной духовности, воспитание богатой и полной ценного содержания индивидуальности.

Особый интерес вызывает сопоставление идей П.Струве со взглядами субъективиста С.Южакова на проблему взаимоотношений личности и культуры. Рассматривая личность и культуру как два фактора общественного развития, С.Южаков, в то же время видит в них антагонистов, поскольку рост культуры ведет к деградации личности.

В результате получается, что если С.Южаков, подчеркивает противоречивый характер взаимоотношений личности и культуры, с преобладанием негативного последней на личность, то П.Струве, в отличие от него, отмечает постоянство и необходимость такого противоречия для развития культурного прогресса. Из рассмотрения проблемы взаимоотношения личности и культуры, логически вытекает формула прогресса П.Струве: всестронне развитая личность выступает - как цель, а общественная организация - как средство. Взаимное уважение и солидарность между людьми - это принцип, на котором построено и держится современное человеческое общество.

В анализе социологии М.Туган-Барановского, Ю.Геккер делает акцент на выявлении особенностей, отличающих его от положений ордотоксального марксизма.

1. Признание наряду с экономическими потребностями и других в качестве важных социальных сил в непрерывном взаимодействии внутри социальных групп. Ю.Геккер 
отмечает некоторое сходство его теории потребностей с теориями социологов Даренндорфа, Лабриола и Смола. Возможно, он придерживался их предположений, но классифицировал по-своему.

Так, М.Туган-Барановский разделяет потребности на 5 групп: физиологические; сексуальные; симпатические; эго-альтруистические; основанные на практических интересах.

2. Непрерывное отклонение социальной деятельности от экономической основы и смещение центра тяжести от физиологических потребностей к духовным составляет суть социального развития. Когда человечество совершенствуется, социальная важность экономического аспекта уменьшается. В этом процессе индивид освобождается от контроля окружающей среды и, хотя общество всегда будет связано с экономическим детерминизмом, но все же оно направлено на социальную эволюцию. Ю.Геккер подчеркивает, что в таком аспекте своей теории общества М.Туган-Барановский больше близок к американским социологам, нежели к К.Марксу.

Подводя итоги анализу некоторых аспектов личности в представлениях русских марксистов, которым мы дополнили видение Ю.Геккера, можно сделать вывод, что именно в контексте легального направления марксизма, с нашей точки зрения, стала восстанавливаться парадигма субъективной школы в истории российской социологии: этическая доминанта социальной теории и социального действия. Поиск теоретических решений, по нашему мнению, продолжился в русле неокантианской школы (Новгородцев, Хвостов и др.) и христианской социологии (Булгаков, Бердяев), переходной ступенью к которым, оказался критический марксизм «легальных марксистов».

\section{Выводы}

Обобщая анализ монографии Ю. Геккера мы пришли к следующим выводам:

1. Американский социолог провел подробный, всесторонний анализ концепций и направлений российской социологии в рассматриваемый им исторический период. Тем не менее, в этом анализе не хватает его собственного мнения, критики или выражения согласия с различными методологическими позициями и подходами российских социологов.

2. В монографии приведено множество прямых цитат из работ российских социологов без конкретного анализа и их оценки американским социологом. Однако, одним из достоинств работы Ю.Геккера является то, что он знакомит западных социологов и мировую общественность с творчеством и первоисточниками российских социологов.

3. Представляют интерес рассуждения Ю.Геккера о будущем социологии. Он убежден, что для нормального ее развития России необходимо освободиться от автократического строя и ликвидировать тем самым детерминацию науки об обществе экономическими, социальными и политическими задачами. Пока существует этот строй, считает он, русская социология будет сохранять свой революционный дух, и ее развитие будет определяться не строго научным.

4. Основным недостатком большей части работ по социологии в России, Ю.Геккер считает узость их проблематики (отсутствие системного подхода), из-за чего они в значительной мере утрачивают научную ценность. В данном контексте мы не согласны с его выводом, и в подтверждение этого была разработана интегральная теория личности на основе трехкомпонентной модели по формированию лидерских качеств руководителей, обосновывающая актуальность и эвристи- 
ческую ценность идей российских социологов конца XIX начала XX вв.

В современных условиях, когда дисфункции в управлении становятся частым явлением в бюрократической системе нашей страны, проявляющиеся в различных нарушениях административно-правового характера, недостаточном внимании к социально-психологическому фактору в управлении, отсутствии гибкости, изменчивости в стиле управления и других соответствующих качественных характеристик руководителя, повышается необходимость в грамотных, высококвалифицированных руководителях, обладающих лидерскими качествами и способных эффективно управлять организацией. Вследствие этого, особую значимость представляет создание социальных технологий формирования профессиональных лидеров. Данные технологии должны основываться на определенной теоретико-методологической базе (Оганян 2014).

Предложенная трехкомпонентная модель по формированию лидерских качеств руководителей и станет такой теоретико-методологической основой. С целью разработки интегральной теории личности нами была сформирована трехкомпонентная модель по формированию лидерских качеств руководителя и показано значение взаимодействия стилей управления, типов организационной культуры и личности руководителя как фактор формирования этих качеств. Для этого, были последовательно выявлены и рассмотрены отдельные элементы этой модели во взаимодействии: стиль управления и

Таблица 1 тип организационной культуры; стиль управления и тип личности руководителя; тип организационной культуры и тип личности руководителя (Оганян 2012: №1; Оганян 2009).

Прокомментируем результаты данного теоретического анализа, представленные в виде трехкомпонентной модели по формированию лидерских качеств руководителей (см. табл. 1).

У руководителя, осуществляющего организационный стиль управления - «команда», в котором высокая степень учета интересов производства сочетается с высокой степенью реализации интересов людей, будет клановый тип культуры в организации, проявляющийся в высокой степени сплоченности коллектива, проявлении преданности делу и преданности организации. Для такого гармоничного руководителя важнейшими общечеловеческими идеалами являются: альтруизм, знание, красота, религия, общество, внешняя деятельность, система, власть.

Страстный тип личности руководителя наиболее эффективно будет управлять организацией в новаторско-аналитическом стиле по Коно. Такой руководитель - энергичный новатор и одновременно хороший организатор. Он отражает следующие элементы менеджерского поведения: преданность фирме, чуткость к новой информации и идеям, способен принять быстрое решение и обеспечить хорошую интеграцию.

Трехкомпонентная модель по формированию лидерских качеств руководителей

\begin{tabular}{|c|c|c|}
\hline $\begin{array}{l}\text { Тип личности } \\
\text { руководителя }\end{array}$ & $\begin{array}{c}\text { Тип } \\
\text { организационной } \\
\text { культуры }\end{array}$ & Стиль управления \\
\hline $\begin{array}{c}\text { Гармоничный } \\
\text { (по Лазурскому) }\end{array}$ & $\begin{array}{c}\text { Клановая } \\
\text { (по Куинну и } \\
\text { Камерону) }\end{array}$ & $\begin{array}{c}\text { Команда } \\
\text { (организационное } \\
\text { управление) } \\
\text { (по Блейку и Мутону) }\end{array}$ \\
\hline
\end{tabular}




\begin{tabular}{|c|c|c|}
\hline $\begin{array}{l}\text { Тип личности } \\
\text { руководителя }\end{array}$ & $\begin{array}{c}\text { Тип } \\
\text { организационной } \\
\text { культуры }\end{array}$ & Стиль управления \\
\hline $\begin{array}{c}\text { Страстный } \\
\text { (по Хеймансу-Ле } \\
\text { Сенна) }\end{array}$ & $\begin{array}{c}\text { Адхократическая } \\
\text { (по Куинну и } \\
\text { Камерону) }\end{array}$ & $\begin{array}{c}\text { Новаторско- } \\
\text { аналитический } \\
\text { (по Коно) }\end{array}$ \\
\hline $\begin{array}{c}\text { Новатор, } \\
\text { деятель, } \\
\text { служитель, игрок, } \\
\text { рационалист } \\
\text { (по Резнику) }\end{array}$ & $\begin{array}{c}\text { Личностная культура } \\
\text { (по Харрисону) }\end{array}$ & $\begin{array}{c}\text { Демократический } \\
\text { (по Лайкерту) }\end{array}$ \\
\hline
\end{tabular}

Эти элементы проявляются в адхократической культуре, главная цель которой - ускорять адаптивность, обеспечивать гибкость и творческий подход к делу, в ситуациях, для которых типична неопределенность, двусмысленность или перегрузка информацией.

Демократический стиль управления будет осуществляться в организации с типом культуры, ориентированной на человека (личностная культура), поскольку в такой организации эффективные руководители будут уделять внимание, прежде всего, человеческим аспектам проблем, стоящих перед подчиненными, и строить отношения, основанные на взаимопомощи. Личность руководителя, управляющего в демократическом стиле можно квалифицировать как новатор, деятель, служитель, игрок, рационалист.

Таким образом, по результатам нашего теоретического анализа, каждому типу организационной культуры соответствует определенный тип личности руководителя, а эффективность управления зависит от определенных психологических, социальных и других индивидуальных особенностей личности руководителя.

Интегральность в трехкомпонентной модели проявляется в том, что личность руководителя рассматривается через: особенности деятельности, выраженной в стиле управления, формирование определенного типа органи- зационной культуры и характеристики типа личности руководителя.

В этом отношении можно проследить продолжение проблематики, идущей от теорий личности представителей различных школ российской социологии середины XIX начала XX вB. Выявим некоторые аспекты, связывающие идеи российских социологов с интегральной теорией личности.

1. Идея интегральной сущности личности развивалась такими российскими социологами как: представителем органической школы Строниным А. и неопозитивистской школы Сорокиным П.

Анализ личности в рукописи Стронина А. «Теория личности» носит междисциплинарный характер. Российский социолог применяет комплексный подход, рассматривая личность с точки зрения, социологии, психологии, социальной психологии, социальной педагогики, этики (Стронин 2013).

В результате, личность по Стронину А. это интегральное понятие, характеризующее человека в качестве объекта и субъекта биосоциальных отношений и объединяющее в нем общечеловеческое, социально-специфическое и индивидуально-неповторимое.

Сорокин П. применяет комплексный подход к анализу личности, учитывая социокультурные, социально-психологические факторы ее развития. Личность рассматрива- 
ется им как интегральная система, включающая в себя (Оганян 2014: № 2):

- поведенческие характеристики, проявляющиеся В особенностях социального взаимодействия и отражающие состояние, развитие общества и культуры;

- деятельность, выражающуюся в творчестве, создании явлений культуры, посредством комплекса рациональных, сверхчувственных, профессиональных и других личностных особенностей;

- духовно-нравственный ресурс, способствующий возрождению общества из кризиса, посредством накопления и увеличения созидательного альтруизма и постоянного морального совершенствования.

2. В целом организационная культура представляет собой достаточно сложную систему, имеющую следующую структуру: ценностнонормативную, организационную, коммуникационную, социально-психологических отношений и др. В этом контексте, связь с идеями представителей различных школ в истории российской социологии выражается в том, что для многих из них ценностно-нормативная основа поведения и деятельности личности являлась одним из важных аспектов ее структуры: неокантианская школа В.Хвостов, П.Новгородцев; субъективная школа - П.Лавров, Н.Михайловский; психологическая школа - Н.Кареев; проблема взаимозависимости личности и культуры в творчестве представителя легального направления марксисткой школы - Струве П.

3. Стиль управления рассматривается нами как индивидуально-типические особенности целостной, относительно устойчивой системы приоритетов, а также способов, методов, приемов управленческого взаимодействия в структуре реализации функций управления. Стиль управления проявляется в специфике деятельности и поведения руководителя. В этой связи можно утверждать, что проблема роли деятельности в развитии личности рассматривалась такими российскими социологами середины XIX века как: представитель психологической школы - Кареев Н. Анализировал сущность общественной деятельности, ее мотивы, цели и средства.

4. В типе личности руководителя выражаются его определенные психологические черты, качества, особенности поведения, характера, частично темперамента. Одной из главных тем в истории российской социологии была роль личности в истории, в которой социологи Лавров П. и Кареев Н. выделяли определенные качества, особенности личности, способствующей достижению социального прогресса в обществе.

Таким образом, интегральная теория личности представляет собой трехкомпонентную модель по формирования лидерских качеств руководителя и сводится к взаимовлиянию и взаимозависимости этих трех компонентов (стиля управления, типа организационной культуры и типа личности руководителя), необходимых для реализации эффективного управления в современных условиях. Идеи российских социологов середины XIX начала XX вв. получили свое преломление на микро уровне через социальнопсихологические аспекты управления.

Наследие отечественной социологии не утратило своей актуальности для понимания и изучения процессов современного российского общества. Этот аспект подчеркивает и Бочкарева В., утверждая, что нельзя считать, что «социология пореформенного периода никак не соотносится с состоянием пореформенной России сегодня. Это связано прежде всего с тем, что процесс развития как дореволюционной, так и современной социологии происходил и происходит в условиях радикального преобразования всех сфер жизнедеятельности общества - социальной, 
экономический, политической, правовой» (Бочкарева 2013: 58).

5. Добросовестно изучив содержание различных течений, и особенно подробно - субъективной школы, американский ученый пришел к заключению, что в силу того, что связи социологических теорий с событиями политической и общественной жизни исключительно тесные, социология как наука в России представляет собой не столько созданный профессионалами вид теоретического знания, сколько выражение позиций лидеров общественного мнения.

Н.Кареев признал известную правоту подобных взглядов. В рецензии на книгу Ю.Геккера он отмечал, что интерес американского социолога к общественным течениям помогал ему объяснять внутренние механизмы самой русской жизни. Однако Ю.Геккер, считает Н.Кареев, неправ, приписывая доминирующее влияние на теоретическую мысль фактора, который должен учитываться лишь в самом общем смысле. Если преувеличивать влияние общественно-политической жизни на русскую социологию, то ре-

\section{ЦИТИРОВАННАЯ И УПОМЯНУТАЯ ЛИТЕРАТУРА}

1. Золотарев, О. (1992). Вклад Н. Кареева в социологию // Рубеж (альманах социальных исследований). № 3.

2. Золотарев, О. (1995). Историко-генетическая социология М.Ковалевского // Рубеж (альманах социальных исследований). № 6-7.

3. Кареев, Н. (1895). Мысли об основах нравственности. СПб.- 177 с.

4. Кареев, Н. (1916). Американская книга о русской социологии // Русские записки. № 4.

5. Кареев, Н. (1901). Мысли о сущности общественной деятельности. СПб. - 175 с.

6. Кукушкина, Е. (2009). История русской социологии. М., Высшая школа. - 486 с.

7. Новикова, С. (1996). История развития соци- шающее значение будет присвоено тем ее чертам, которые на самом деле таковыми не являются. Смещение акцентов определило сделанный Геккером вывод: русская социология - это не столько результат реализации «чисто теоретического, строго научного интереса к проблемам отвлеченного познания общественных явлений в их статике и динамике», сколько «воспроизведение реальных и практических задач русской жизни с ее злобами дня» (Кареев 1916: № 4, 297).

В 1990-е гг. историком О.Золотаревым были сделаны первые попытки перевода отдельных глав монографии Ю.Геккера: глава 4 из раздела о субъективной школе - «Вклад Н. Кареева в социологию» (Золотарев 1992: № 3) и «Историко-генетическая социология М.М.Ковалевского» (Золотарев 1995: № 6-7).

В представленной монографии нами впервые сделан полный перевод книги Ю. Геккера на русский язык.

ологии в России. М. - 288 с.

8. Оганян, K. (2013). "Analysis of Social and Psychological Factors of Management in E. de Roberti's "Psychological Sociology". Теория и практика современной науки: материалы X Международной научно-практической конференции. Москва: изд-во Спецкнига.

9. Она же Анализ и оценка субъективной школы российской социологии в трудах западных социологов конца XIX - начала XX вB. // Вестник Балтийской педагогической академии. Вопросы современной практической психологии и социологии. Теория и практика. Вып. 110. СПб. 2013.

10. Анализ личности в российской социологии: история и современность. М.: ИНФРА-М., 2015. - 350 c.

11. Анализ личности в социально-философской 
концепции П.Струве как представителя легального направления марксистской школы российской социологии//Научный журнал «Вестник КРСУ», Т. 14, № 6, 2014.

12. Анализ некоторых аспектов личности в социологическом творчестве П.Сорокина// Научный журнал «Вестник НГУЭУ», № 2, 2014.

13. Анализ некоторых аспектов развития личности в творчестве Г.Плеханова как представителя ортодоксального направления марксисткой школы российской социологии //Научный журнал «Вестник КРСУ», Т. 14, № 6, 2014.

14. Анализ роли личности в историческом развитии по концепции Н.Кареева// Электронный периодический научный журнал «SCIARTICLE.RU», № 2 (октябрь), 2013.

15. Взаимоотношения личности и общества в социологических концепциях Н. И. Кареева и П.Лилиенфельда// Концепт. - 2013. - № 07 (июль).

16. Взаимоотношения типов организационной культуры, стилей управления и типов личности руководителя // Современные проблемы науки и образования, № 1, 2012.

17. Историко-социологический анализ нравственной личности в концепции Н.Кареева и А.Стронина // Фундаментальные исследования, 2013, № 8 (часть 5).

18. История российской социологии. Саарбрюкен: Palmarium Academic Publishing, 2013 452.

19. Концепции личности в субъективной и органической школах российской социологии // Известия Российского государственного педагогического университета им. А.Герцена. - СПб., 2012. - N 146.

20. Концепции личности в субъективной школе российской социологии: социологический анализ. СПб.: СПбГЭУ, 2012. - 130 с.

21. Концепция личности в трудах С.Южакова // Вестник Санкт-Петербургского государствен- ного университета. Серия 12. 2012. Вып. 3.

22. Личность и общество в социально-правовой концепции Н.Коркунова//Международный научно-исследовательский журнал. Екатеринбург.: ООО «Имплекс», № 6 (13), 2013. Ч. 3.

23. Некоторые рассуждения о нравственной личности в социологии Хвостова В. В контексте духовно-нравственного кризиса современного общества // Восьмые Ковалевские чтения / Материалы научно-практической конференции 15-16 ноября 2013 года / Отв. редактор: Ю.Асочаков. СПб., 2013.

24. Рукопись Стронина А. «Теория личности» как социокультурная ценность для развития отечественной социологии // Социология в системе научного управления [Электронный ресурс]: Материалы IV Всероссийского социологического конгресса/ИС РАН, ИСПИ РАН, РГСУ. - М.: ИС РАН, 2012; Социальные технологии формирования лидерских качеств у будущих руководителей в вузовской среде. М.: НИЦ ИНФРА-М, 2014. (Научная мысль). $140 \mathrm{c}$.

25. Социологический анализ личности в рукописи Стронина А. «Теория личности» и современность // Современные проблемы науки и образования. - 2011. - № 5.

26. Анализ личности в субъективной школе российской социологии // Ежеквартальный научно-методический журнал «Научная мысль». № 2-3(10) 2013.

27. Сравнительный анализ концепции личности Лаврова П., Михайловского Н. и Стронина А. // Социология и общество: глобальные вызовы и региональное развитие [Электронный ресурс]: Материалы IV Очередного Всероссийского социологического конгресса // РОС, ИС РАН, АН РБ, ИСППИ. - М.: РОС, 2012;

28. Теория героев и толпы как проявление психологической ориентации социологии Н.Михайловского // Традиционные духовные цен- 
ности и современная образовательная практика: материалы II всероссийской научнометодической очно-заочной конференции // отв. ред. С.Бойко. - Череповец: Филиал СПбгЭУ в г. Череповце, 2013.

29. Формирование образа современного руководителя на основе критически мыслящей личности в концепции П.Лаврова // Вестник ИНЖЭКОНА, серия: гуманитарная науки. № 4 (55), 2012.

30. Влияние типа личности руководителя на стиль управления. Социально-психологическое обеспечение профессиональной деятельности. Тематический сборник БПА. СПб., 2009.

31. Стронин, А. (2013). Теория личности (по материалам рукописи)/ Монография /Авт.-сост. научного исследования К.Оганян. - 2-е изд., доп. и перераб. - М.: ИНФРА-М. - 188 с. (Серия: Научная мысль).

32. Струве, П. (1926). Заметки писателя 7. Возрождение. № 352. Париж.

33. Струве, П. (1999). Интеллигенция и народное хозяйство. // Струве П. Избранные сочинения. - М.: «Российская политическая энциклопедия» (РОССПЭН).

34. Hecker, J. (1915). Russian Sociology. A Contribution to the History of Sociological Thought and Theory // With a Foreword of Sidney Webb. New York: The Columbia University Press, 309 p.

35. Maus, H. (1962). A Short History of Sociology. L. 222 p.

36. Vucinic, A. (1976). Social Thought in Tsarist Russia. The Quest for a General Science of Society. 1861-1917. Chicago, 230 p.

Карина ОГАНЯН

\section{СОЦИОЛОГИЧЕСКИЙ АНАЛИЗ МОНОГРАФИИ Ю. ГЕККЕРА «РУССКАЯ СОЦИОЛОГИЯ»}

\section{РЕЗЮМЕ}

В статье проводится социологический анализ монографии американского социолога Геккера «Русская социология. Вклад в историю социологической мысли и теории». Проанализирована специфика рассмотрения школ и направлений русской социологии в монографии Геккера и показаны преимущества и недостатки взглядов американского социолога. Научная цель его работы - представить западному читателю анализ различных школ и направлений русской социологии в историческом контексте. Впервые в истории социологии будет издана переведенная автором с английского языка работа Геккера. Американский социолог провел подробный, всесторонний анализ концепций и направлений российской социологии в рассматриваемый им исторический период. Тем не ме- нее, в этом анализе не хватает его собственного мнения, критики или выражения согласия с различными методологическими позициями и подходами российских социологов. В монографии приведено множество прямых цитат из работ российских социологов без конкретного анализа и их оценки американским социологом. Однако, одним из достоинств работы Геккера является то, что он знакомит западных социологов и мировую общественность с творчеством и первоисточниками российских социологов. Добросовестно изучив содержание различных течений, и особенно подробно - субъективной школы, американский ученый пришел к заключению, что в силу того, что связи социологических теорий с событиями политической и общественной жизни исключительно тесные, со- 
циология как наука в России представляет собой не столько созданный профессионалами вид теоретического знания, сколько выражение позиций лидеров общественного мнения.

Основным недостатком большей части работ по социологии в России, Геккер считает узость их проблематики (отсутствие системного подхода), из-за чего они в значительной мере утрачивают научную ценность. В данном контексте мы не согласны с его выводом, и в подтверждение этого была разработана интегральная теория личности на основе трехкомпонентной модели по формированию лидерских ка- честв руководителей, обосновывающая актуальность и эвристическую ценность идей российских социологов конца XIX начала XX вB.

Ключевые понятия: русская социология, личность, субъективная школа, общество, прогресс, борьба за индивидуальность, теория героя и толпы, марксистская социология, роль личности в истории, идея личной годности, взаимоотношения личности и культуры, трехкомпонентная модель по формированию лидерских качеств руководителей.

чunpqu OZUと3Uと

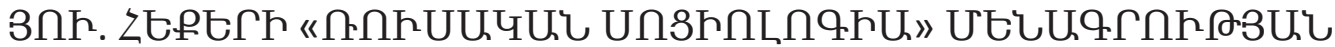

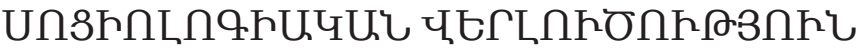

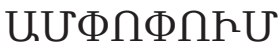

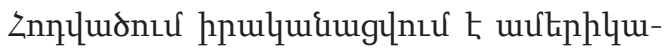
gh unghnцnq 3nı. Ztptiph «nntuulquir unghnŁnqhu. \&innpnud unghnınqhulquir ưnph le

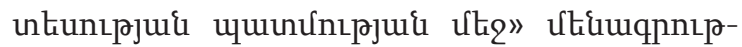

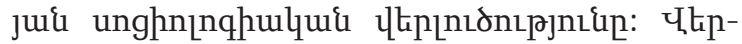

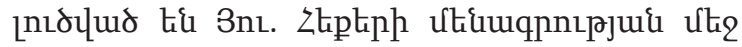

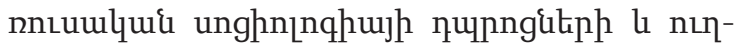

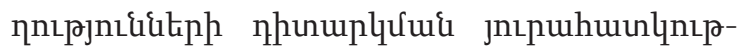

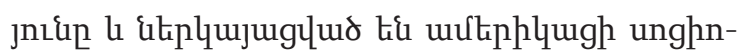

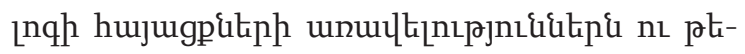

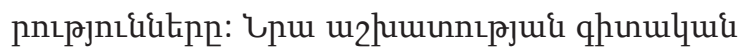

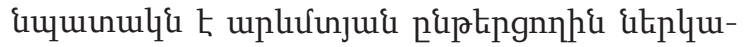
juigits nntuulquis unghnцnqhujh unupptp

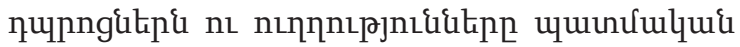

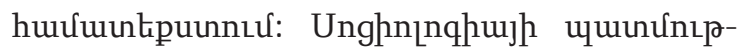

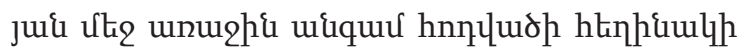

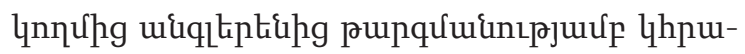

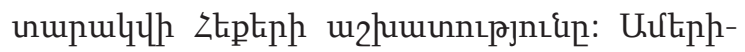

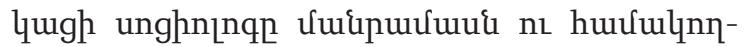

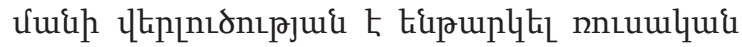

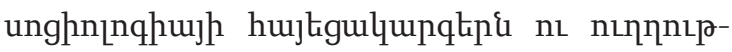

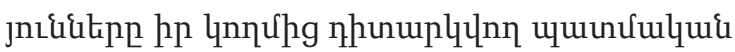

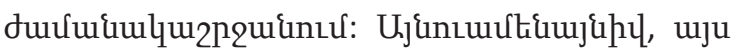

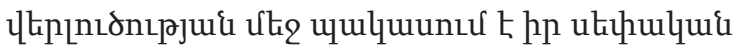

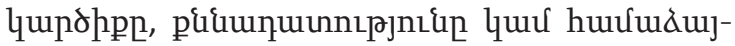

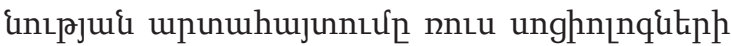

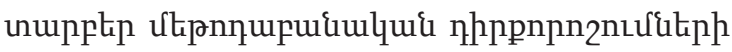

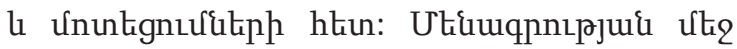

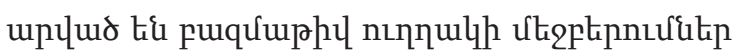

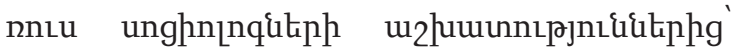

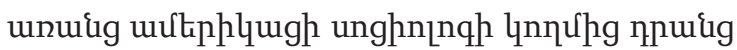

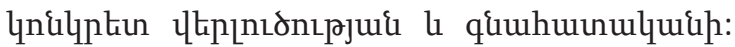

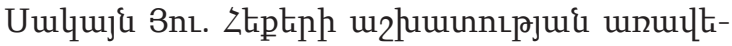

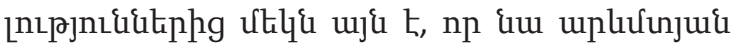

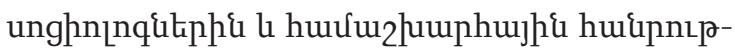

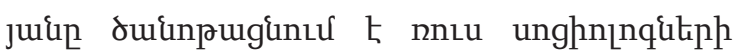

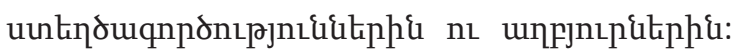

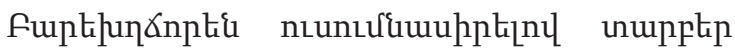

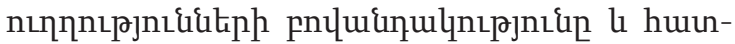

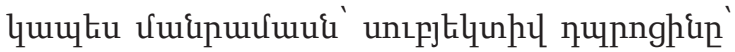




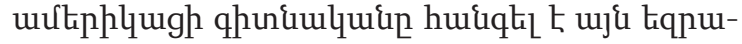

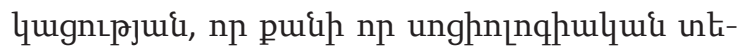

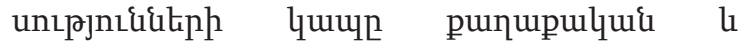
huuupulquluis ljuiph hpunupànıpjnı\&-

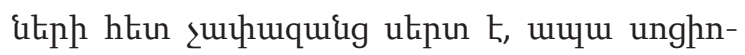

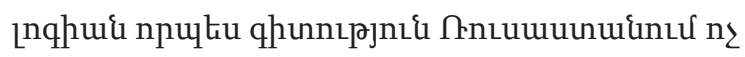

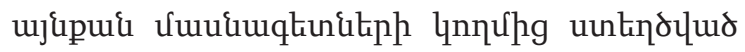
untumlquis qhuntihph àl t, nppuí humupuquilus qundhph unuqunpnikph nhppnpn-

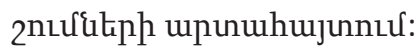

3nt. Ztiptinn Rntuuuunuintu unghn!n-

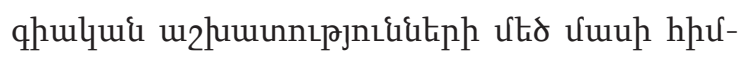

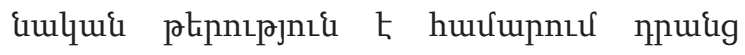

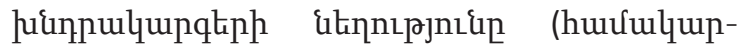

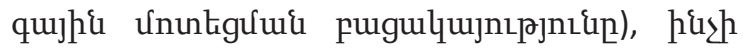

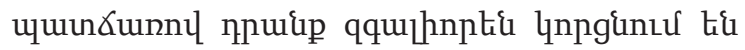
pptigg qhonulquis updtipn: U.ju huruu-

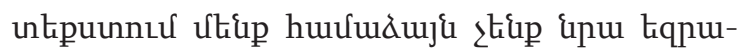

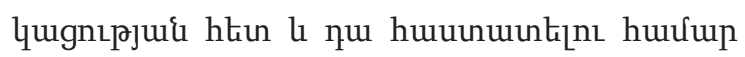

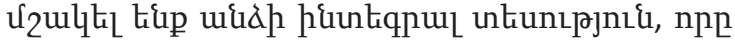

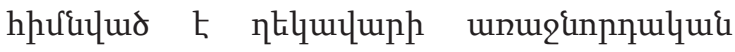

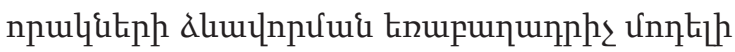

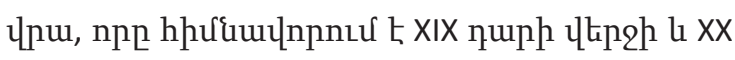
nuph ulqph nnsuulqui unghnцnquteph qunu-

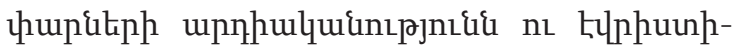
quiluid undtip:

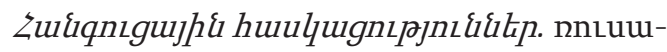

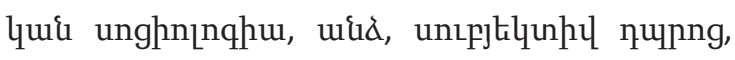

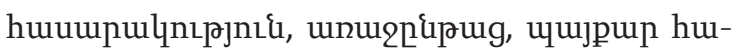

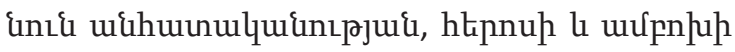
uthunıpjnı\&, Uuppuhunulqui unghnцnqhu,

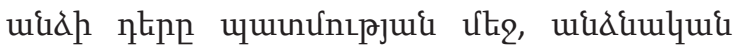

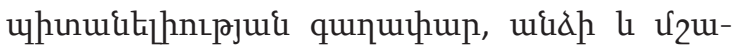

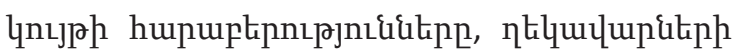

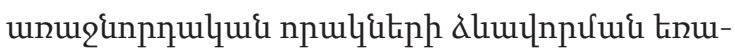
punumph unntis:

Karina OHANYAN

\section{SOCIOLOGICAL ANALYSIS OF J.HECKER'S MONOGRAPH "RUSSIAN SOCIOLOGY"}

\section{ABSTRACT}

The American sociologist J. Hecker's sociological monograph "Russian sociology. Contribution to the history of sociological thought and theory" is analyzed in the article. The specifics of of consideration of Russian sociology's schools and directions in J.Hecker's monograph is analyzed and the advantages and disadvantages of the American sociologist views are shown. The scientific goal of his work is to introduce to the Western reader the analysis of Russian sociology's different schools and directions in historical context. For the first time in the history of sociology, will be published J. Hecker's work translated by the author from English. American sociologist conducted a detailed, comprehensive analysis of the Russian sociology's concepts and directions in the historical period under review. However, this analysis lacks author's opinion, criticism or expression of consent to different methodological positions and approaches of Russian sociologists. The book presents many direct quotations from the works of Russian sociologists without a specific analysis and evaluation by the American sociologist. However, one of the advantages of J. Hecker's work is that it introduces Western sociologists and the international community the works and primary sources of Russian sociologists. Conscientiously studying the contents of the various movements, and in particular detail the subjective school, American scientist came to the conclusion that in due of the fact that the 
connection of sociological theories of the political events and social life are extremely close, sociology as a science in Russia is not so much created by professionals type of theoretical knowledge but rather an expression of the positions of leaders of public opinion.

The main disadvantage of most sociological works in Russia, J. Hecker considers the narrowness of their problems (lack of a systemic approach), because of which they largely lose their scientific value. In this context, we do not agree with his conclusion, and in support of this can be mentioned the integral theory developed on the basis of a three-person model for the formation of leadership qualities of managers, that prove the urgency and heuristic value of ideas of Russian sociologists of the late XIX beginning XX centuries.

Key concepts: Russian sociology, the personality, the subjective school, society, progress, the struggle for individuality, the theory of the hero and the crowd, Marxist sociology, the role of personality in history, the personal life's idea, the relationship of personality and culture, three-component model for the formation of leadership qualities. 